\title{
THE ACCUMULATION OF METALS IN Polygonum aviculare L. IN AREA OF THE KRALJEVO CITY
}

\author{
Monika Radulović ${ }^{1}$, Milan S. Stanković ${ }^{1}$, Zoran Simić \\ Miloš Radaković ${ }^{1}$ and Marina Topuzović ${ }^{1}$ \\ ${ }^{1}$ Institute of Biology and Ecology, ${ }^{2}$ Institute of Chemistry, \\ Faculty of Science, University of Kragujevac, Radoja Domanovića 12, \\ 34000 Kragujevac, Republic of Serbia \\ E-mail: monikamoka88@gmail.com
}

(Received April 4, 2014)

\begin{abstract}
Elevated heavy metal concentrations cause environmental pollution. Our study examines the content of heavy metals $(\mathrm{Pb}, \mathrm{Ni}, \mathrm{Mn}, \mathrm{Fe}$ and $\mathrm{Cu}$ ) in the aboveground parts of Polygonum aviculare L. (Polygonaceae) sampled from five different locations in the city of Kraljevo and its surroundings. In order to evaluate the bioindicative ability of $P$. aviculare we have chosen localities which had different level of contamination. The analysis of heavy metals in the plant material was conducted by atomic absorption spectrophotometry. There is a correlation between the higher concentrations of $\mathrm{Pb}, \mathrm{Cu}, \mathrm{Ni}$, $\mathrm{Mn}$ and $\mathrm{Fe}$ measured in plant tissues and environmental pollution caused by traffic. Other emission sources and soil composition are considered to be an important influence on the quantity of metals in plants. Based on the results, the species $P$. aviculare can be used as an important bioindicator of habitat pollution by heavy metals.
\end{abstract}

Keywords: Kraljevo, traffic, $\mathrm{Pb}, \mathrm{Ni}, \mathrm{Mn}, \mathrm{Fe}$ and $\mathrm{Cu}$, Polygonum aviculare $\mathrm{L}$.

\section{INTRODUCTION}

A large number of compounds, gas, liquid and solid substances can be major enviromental pollutants. If their concentrations are higher than those allowed, then they endanger functioning and the balance of the habitat. Pollution is mainly caused either by natural phenomena or as a result of the emissions of pollutants from industry, energetic, transport and anthropogenic factors (NRIAGU and PACYNA, 1988).

As the number of vehicles is on the increase in the past few decades, traffic has become a very important source of heavy metals and other environmental pollutants (PRIMAULT, 1958; FidORA, 1972; JoHnSON, 1980; MEMMON et al., 2001; FAKAYODE and OlU-OwOLABI, 2003; DAVYdOVA, 2005; STANKOVIC et al., 2008). Emissions from heavy traffic contain potentially toxic metals such as lead $(\mathrm{Pb})$, cadmium $(\mathrm{Cd})$, zinc $(\mathrm{Zn})$, copper $(\mathrm{Cu})$ (NDIOKWERE, 1984; Ho and TAI, 1988; BENFENATI et al., 1992; CARLOSENA et al., 1998; GARCIA and Millán, 1998; IMPERATO et al., 2003; VIARD et al., 2004; ÇELIK et al., 2005), and nickel (Ni) (SUZUKI et al., 2008; ATAYESE et al., 2009).

Heavy metals are emitted into the atmosphere as aerosols. They are transported up to several kilometers away from their sources and transferred to the soilby wet or dry deposition. 
This precipitated metals pollute natural waters and terrestrial and aquatic living organisms. Transfer of metals in the soil from the atmosphere is an important part of their biogeochemical cycle (CizMECIOGLU and Muezzinoglu, 2008). Heavy metals reaching the soil remain present in the pedosphere for a long period of time, even after removing the pollution sources (IMPERATO et al., 2003).

Metals are also natural components in soil (LASAT, 2000). All plants have the ability to accumulate heavy metals from land and water as these are essential for their growth and development. These metals include $\mathrm{Mg}, \mathrm{Fe}, \mathrm{Mn}, \mathrm{Zn}, \mathrm{Cu}$, Mo and Ni (LANGILLE and MaCLEAN, 1976). Certain plants also have the ability to accumulate heavy metals that have unknown biological function. $\mathrm{Cd}, \mathrm{Cr}, \mathrm{Pb}, \mathrm{Co}, \mathrm{Ag}, \mathrm{Se}$ and $\mathrm{Hg}$ are metals which belong to this group (HANNA and GRANT, 1962; BAKER and BROOKS, 1989).

However, elevated concentrations of both essential and non-essential metals can result in growth inhibition and toxicity of plants. Unlike the organic matter, they are non-biodegradable and can undergo global ecological circles. Heavy metals through plants get into the food chain, where they have cumulative effect on the animal and the human body, manifesting their harmful effects in tissues and organs. Symptoms of toxicity in plants in the presence of excessive amounts of heavy metals may be due to a range of interactions at the cellular - molecular level (HALL, 2001). Various pollutants can cause damage to plants, especially in the vegetative parts. In the presence of some pollutants, leaves show typical necrotic areas together with changes in stomata, epidermis and mesophyll (LoRENZINI, 1999). Metal stress affects photosynthesis, chlorophyll fluorescence and stomatal resistance (MONNI et al., 2001). In addition, pollutants can enter the soil and alter its $\mathrm{pH}$, causing root injury. The harmful effects of air pollutants can generate plant morphological and physiological changes affecting the development of the reproductive apparatus and consequently plant fertility (REZANEJAD, 2007). Pollutants can affect pollen viability, germination and tube growth (DICKINSON, 2000; REZANEJAD, 2009). However, there are plant species that thrive in environments contaminated with heavy metals. "Metallophytes", "hyper accumulative plants" or "heavy metal flora" are terms for describing the plants able to accumulate large amounts of heavy metals in their parts (DE VARENNEST et al., 1996; ERNST, 1996).

The high accumulation of heavy metals in plant tissues suggests the important role of plant species as bioindicators of environmental pollution (TEN-HOUTEN, 1983; PRASAD and FREITAS, 2003). Plant biomonitoring is alow-cost and valuable method of examining the effect of different airand environment pollutants (OLIVA et al., 2007). Due to its above mentioned ability to receive and store quantities of certain metals, vegetation is an effective indicator of the pollution level. As this absoption of pollutants can be a long term process, it is the part of more complex and again longer in terms of time, evaluation of enviromental pollution (MCGEOCH, 1998).

The aim of this investigation was to determine the level of environmental pollution in Kraljevo region caused by traffic, through experimental assessment of heavy metal concentrations $(\mathrm{Pb}, \mathrm{Ni}, \mathrm{Cu}, \mathrm{Fe}$ and $\mathrm{Mn})$ in the aboveground parts of the plant populations of $P$. aviculare (Polygonaceae). This plant was chosen as a sample because it grows in different areas of Kraljevo, constantly following the human settled teritorries, in which the level of pollution varies as a result of different factors.

\section{MATERIAL AND METHODS}

\section{Investigated area}

City of Kraljevo is located in the central part of Serbia at $43^{\circ} 43^{\prime} \mathrm{N}$ and $20^{\circ} 41^{\prime} \mathrm{S}$. It occupies the area around the lower course of the river Ibar and the middle course of the river Western Morava. The official number of registered vehicles in Kraljevo is estimated at 30.650 registered cars, 2.940 trucks and 246 buses. Therefore, the circulation of traffic is considered to 
be one of the pollutants which most adversely affect the Kraljevo environment. The total length of public roads in the territory of Kraljevo is $567 \mathrm{~km}$, of which $102 \mathrm{~km}$ or $18 \%$ are the main roads, regional roads is $140 \mathrm{~km}$ or $24.70 \%$, and the remaining $325 \mathrm{~km}$ or $57.30 \%$ of the total road network belongs to the category of local roads.

\section{Sampling and preparation of plant material}

Samples of Polygonum aviculare were collected at the end of the growing season in September $2011^{\text {th }}$ at five different locations in Kraljevo and surrounding: 1. near the Ibar highway, 2. city center 3. Ibar riverside, 4. Mataruška spa-center, and 5. Drakčići village. For analysis, above-ground parts of the plants (stems, leaves and flowers) were used. Collected plant material was dried at the room temperature, after which it was completely dried (Binder/Ed15053) at a temperature of $105{ }^{\circ} \mathrm{C}$. The dried plant material was milled and prepared for analysis.

\section{Sample preparation procedure}

Measured sample ( $3 \mathrm{~g}$ ) was transferred in Kjeldahl flask and mixed with $20 \mathrm{ml}$ of concentrated $\mathrm{HNO}_{3}$. Reaction mixture was heated to dryness. Treatment was repeated until the solution become clear, and nitric vapors stopped to release. After that, contents was cooled and mixed with $6 \mathrm{ml}$ of concentrated $\mathrm{HClO}_{4}$. The next step was drying until the content evaporated to $3 \mathrm{ml}$ volume. Obtained samples were mixed with distilled water and filtered. Determination of heavy metals in samples was conducted using atomic absorption spectrophotometer - PerkinElmer Company Model 3300/96 with the MHS-10 hydride system and PC was used (Faculty of Science, University of Kragujevac). Concentrations of metals in plant material are expressed in $\mathrm{mg} / \mathrm{kg}$.

\section{RESULTS AND DISSCUSION}

Plants are good indicators of air pollution and land quality. The monitoring of metal concentrations in plant tissues indicates the presence and intensity of pollution in the environment. Previous studies used different plant species as bioindicators: Pinus nigra, Taraxacum officinale, Tilia tomentosa, Robinia pseudoacacia, Morus alba (NORMANDIN et al., 1999; AKSOY et al., 2000; GHOLAMI, 2012). The results of the research on the concentration of the tested metals show that the plant $P$. aviculare can be successfully used in plant biomonitoring, primarily because of its favourable ecological characteristics.

The concentration of $\mathrm{Pb}$ in the aboveground parts of species $P$. aviculare sampled from five different locations in the city of Kraljevo and its surroundings showed on the Figure 1 . The results show that the concentrations of $\mathrm{Pb}$ considerably vary, from 0 to $17.7 \mathrm{mg} / \mathrm{kg}$, depending on the locality. The highest concentration of $\mathrm{Pb}(17.7 \mathrm{mg} / \mathrm{kg})$ was measured in a sample from the location near the Ibar highway. The results suggest that the increased concentration of $\mathrm{Pb}$ in this sample is a result of the intensive traffic that takes place on this type of roads (with a large number of high speed vehicles).

Lower concentrations of $\mathrm{Pb}(8.5 \mathrm{mg} / \mathrm{kg})$ were found at the location 2 - city center where traffic is also intense but not as much as on the first location, near the highway. The presence of elevated concentrations of $\mathrm{Pb}$ in the aboveground parts of $P$. aviculare sampled in the center of Kraljevo is a result of a large number of vehicles and its longer retention. At the location 3 near the Ibar riverside, the concentration of $\mathrm{Pb}$ could not be detected, which indicated that at this point $\mathrm{Pb}$ is present in very small concentrations or completely absent. Values obtained for the concentration of $\mathrm{Pb}$ in this sample indicate that soil along the river is characterized by lower degree of metal pollution because soil has been washed by the water. The above-ground parts of $P$. aviculare species tested on location 4 - Mataruška spa-center, contained significantly lower concentrations of $\mathrm{Pb}(3 \mathrm{mg} / \mathrm{kg})$, especially in comparison to the first two sites. 


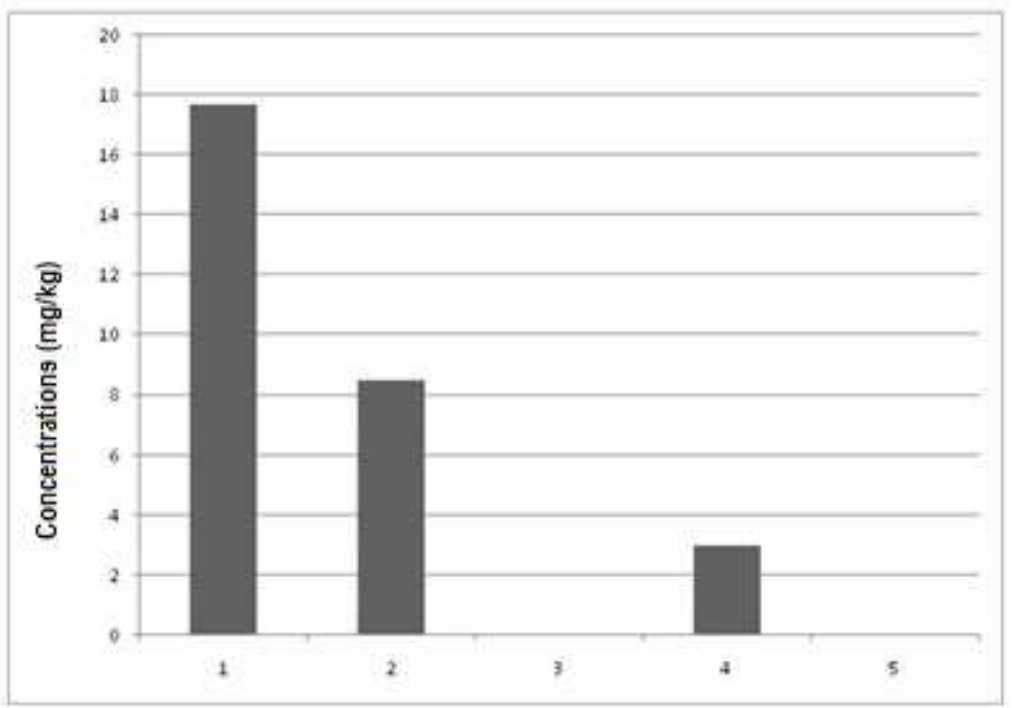

Fig. 1. Concentration of $\mathrm{Pb}$ in the aboveground parts of the plant $P$. aviculare,

in the territory of Kraljevo (1. location near the Ibar highway, 2. city center, 3. location near the Ibar riverside, 4. Mataruška spa-center, 5. Drakčići village near Kraljevo).

On the location 5 - Drakčići, the concentration of $\mathrm{Pb}$ could not be detected or it was found in small quantities. The reason for this may be less intense traffic in the villages, as well as the distance from the highway and towns where large concentrations of heavy metals are detected. The results suggest that the intensity of pollution has influence on the increase of the existing concentrations of the examined metals in plants.

Qasem and Kamal conducted the study in which they claim that lead is probably the most important pollutant of all heavy metals. Namely, all experiments showed that vehicles driving closer to the highway pollute the environment more (QASEM and KAMAL, 1999). As the distance from the road increased, the $\mathrm{Pb}$ level fell sharply reaching the normal soil lead level, which was estimated to be less than $7 \mu \mathrm{g} / \mathrm{g}$.

The same explanation could be done for obtained results regarding plant $\mathrm{Cu}$ concentration shown in Figure 2. The highest concentrations were found in the aboveground parts of $P$. aviculare sampled at locations 1 - near the Ibar highway $(8.2 \mathrm{mg} / \mathrm{kg})$ and 2 - the city center $(8.6 \mathrm{mg} / \mathrm{kg})$. Concentrations are little lower on the location 4 - Mataruška spa-center (5.6 $\mathrm{mg} / \mathrm{kg}$ ). The lowest concentrations of $\mathrm{Cu}$ were detected at the locations 3 - Ibar riverside (4.5 $\mathrm{mg} / \mathrm{kg}$ ) and 5 - Drakčići $(4.7 \mathrm{mg} / \mathrm{kg})$. This may indicate that traffic is not the only source of $\mathrm{Cu}$ on the analysed territories. Based on the obtained results we can establish the relationship between the $\mathrm{Pb}$ and $\mathrm{Cu}$ concentrations, traffic distance and frequency. There are many studies that confirm that the intensive traffic is the source of $\mathrm{Pb}$ in urban areas due to the use of gasoline with lead additive (SOYLAK et al., 2000; AKSOY et al., 2000) and that $\mathrm{Cu}$ originates from car tires (ANGOLETTA et al., 1993; HANDREEK, 1994; COOK and SGARDELIS, 1994).

Lead exerts toxic effects on plants in high concentrations, because many plants have mechanisms for cell detoxification, such as $\mathrm{Pb}$ storage in insoluble form, as well as mechanisms to limit translocation within the plant. Characteristics of accumulation and toxic effects in plants are genetically controlled. $\mathrm{Pb}$ causes damage to cell membranes, disrupting the process of mitosis. It also inhibits plant growth, synthesis of ATP and the formation of structural proteins. Lead affects the water intake as well as the level of transpiration. Higher concentrations of $\mathrm{Pb}$ disable the processes of pollen germination and seed growth to a great extent (KASTORI and Petrović, 1993; PALlaVi and RAMA, 2005). 


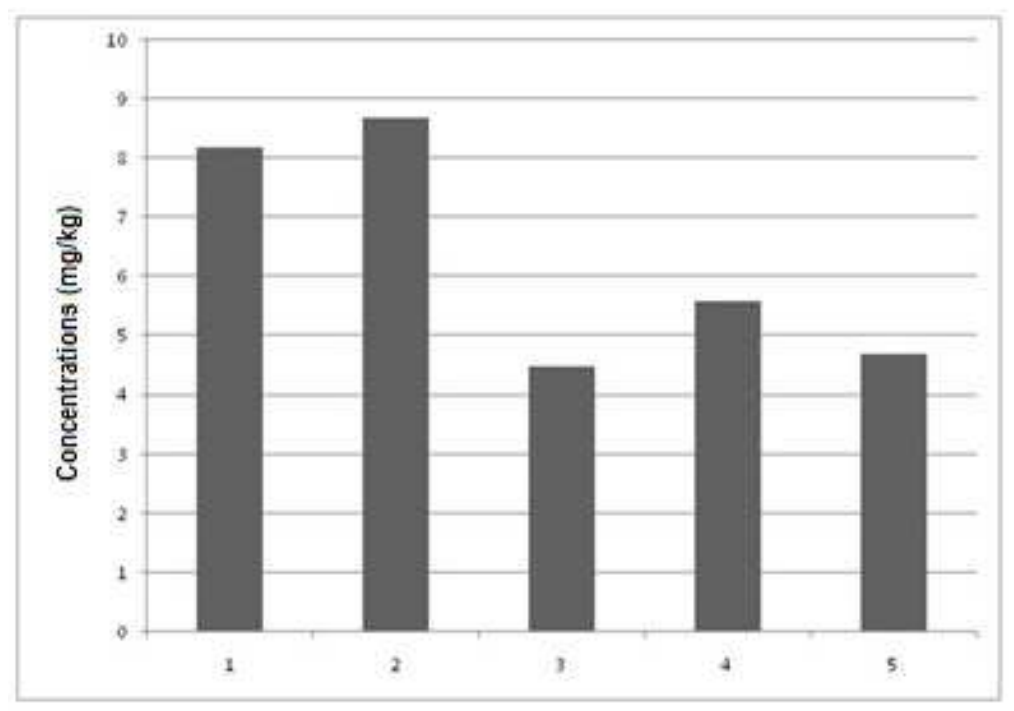

Fig. 2. Concentration of $\mathrm{Cu}$ in the aboveground parts of the plant $P$. aviculare, in the territory of the Kraljevo (1. locality near the Ibar highway, 2. city center, 3. city - Ibar riverside, 4. Mataruška spa-center, 5. Drakčići village near Kraljevo).

According to the results shown in Figure 3, different values for $\mathrm{Ni}$ accumulation in $P$. aviculare depending on the locality $(6.7$ to $17 \mathrm{mg} / \mathrm{kg})$. The highest concentrations of $\mathrm{Ni}$ of the studied samples were recorded at locations 1 - near the Ibar highway $(15.52 \mathrm{mg} / \mathrm{kg}), 2$ - city center $(14 \mathrm{mg} / \mathrm{kg})$ and 3 - Ibar riverside $(17 \mathrm{mg} / \mathrm{kg})$, where the traffic is the most intense. The approximate Ni concentration of $12 \mathrm{mg} / \mathrm{kg}$ was observed at the site 5 - Drakčići, with the least intense traffic, while the lowest Ni concentration $(6.7 \mathrm{mg} / \mathrm{kg})$ was in the sample from the site 4 Mataruška spa center, where traffic is more intense than in the countryside.

This significant difference was observed in the concentration of $\mathrm{Ni}$ in various locations, indicating the presence of contamination at the site of heavy traffic. However, Ni is not the major polluting element which is consistent with the research conducted on the territory of Belgrade. $20 \%$ of the total Ni emissions in the atmosphere is the result of traffic (STANKOVIĆ et al., 2011). According to California Air Resources Board and Department of Health Services, vehicles using gasoline and diesel fuel contribute to total $\mathrm{Ni}$ emissions to the atmosphere with 54-72 tons per year (1991). The concentration of nickel in the diesel exhaust pipes range from 500 to 10.000 $\mathrm{mg} / \mathrm{l}^{-1}$ (FREY and CORN, 1967).

Even though that physiological role of $\mathrm{Ni}$ has not been fully determined, opinion is that it is a necessary microelement in the metabolic processes of higher plants (vascular plants), (MENGEL and KIRKBY, 1982). On the contrary, toxicity of Ni excesive tissue concentrations for plants is well known. Plants suffering with Ni toxicity show necrosis on the leaf tips and margins. Ni rapidly enters the plant root, inhibits its growth, and inhibits a large number of plant enzymes such as those of the Calvin cycle and chlorophyll biosynthesis and consequently decreases the photosynthetic activity. $\mathrm{Ni}$ alters the plant water relations and increases the antioxidant system (PANDEY and SHARMA, 2002; Ali et al., 2008).

The concentrations of the other two metals, $\mathrm{Mn}$ and $\mathrm{Fe}$ in all investigated sites varied a lot. Figures 4 and 5 show that greater concentrations are present mainly on the first three locations where the traffic is intense. Figures also imply the differences in values of concentrations. This indicates that traffic is not directly related to their concentration in the plants and that there are other sources of pollution on the territory of Kraljevo and its surroundings which contribute to the presence of these metals in the environment. Cause may also be the different composition of the soil. 


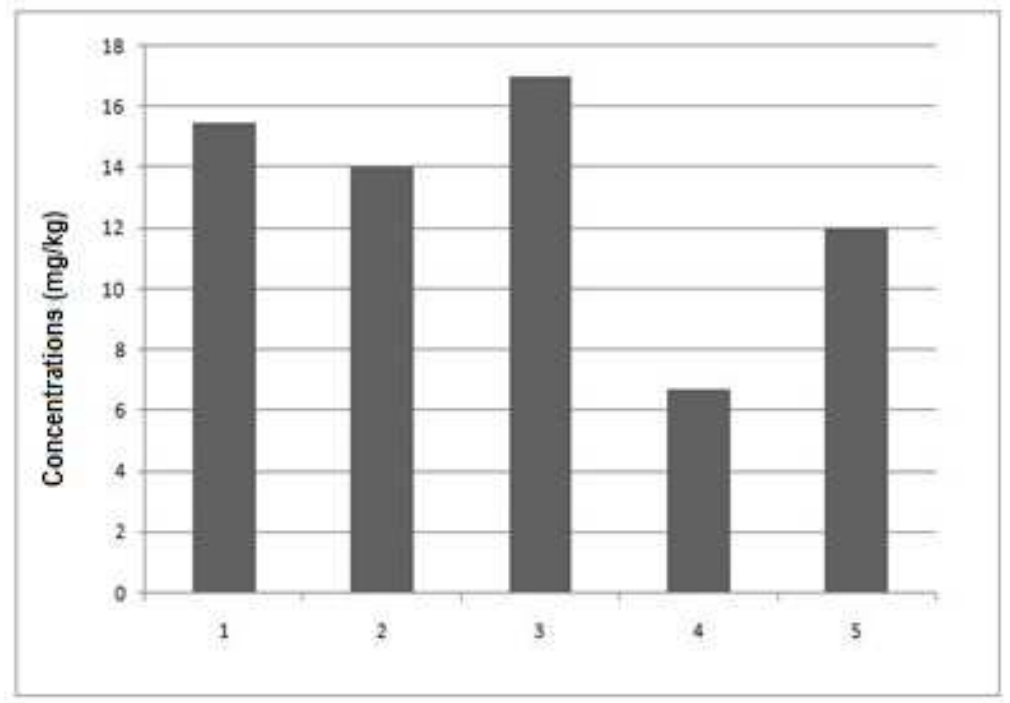

Fig. 3. Concentration of $\mathrm{Ni}$ in the aboveground parts of the plant $P$. aviculare,

in the territory of the Kraljevo (1. locality near the Ibar highway, 2. city center, 3. Ibar riverside,

4. Mataruška spa-center, 5. Drakčići village near Kraljevo).

In Belgrade, the concentrations of Mn vary due to the characteristics of the soil. The results of research related to the accumulation of $\mathrm{Mn}$ on the examined area show that localities on Avala contain higher concentrations of Mn than the locality in the centre of Belgrade. This clearly implies that Mn concentration increase in plants is not directly related to the traffic as the primary source but to the type of soil (STANKović et al., 2011). Minimum concentrations of Fe were found in location 4 - Mataruška spa center (471 mg/kg) and 5 Drakčići (502 mg/kg).

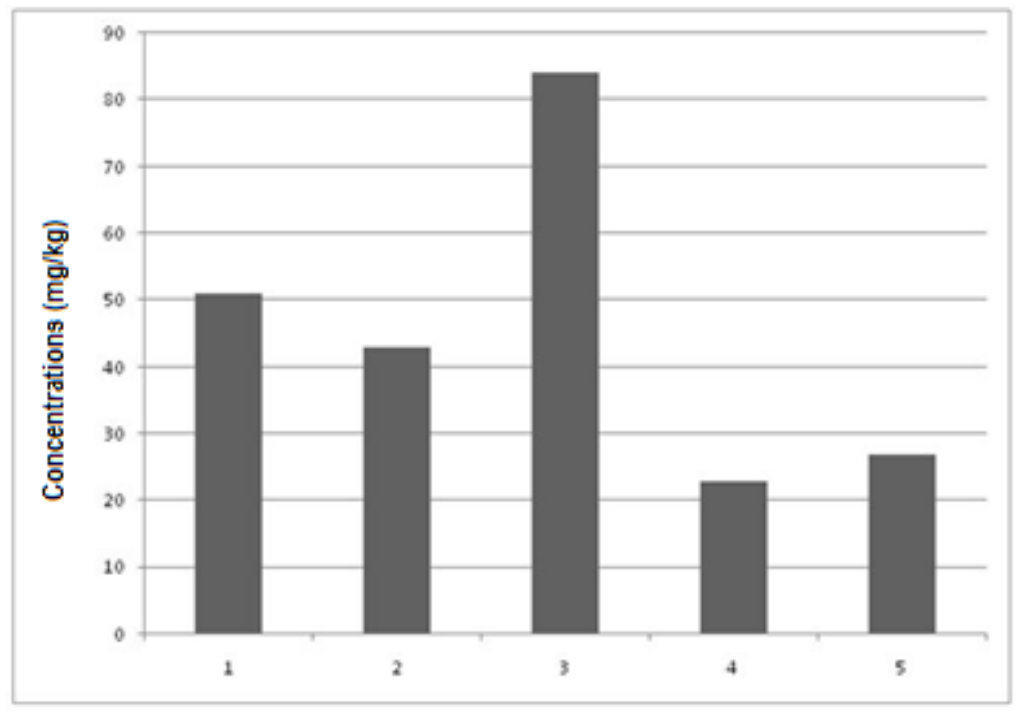

Fig. 4. Concentrations of $\mathrm{Mn}$ in the aboveground parts of the plant $P$. aviculare, in the territory of the Kraljevo (1. locality near the Ibar highway, 2. city center, 3. Ibar riverside, 4. Mataruška spa-center, 5. Drakčići village near Kraljevo). 


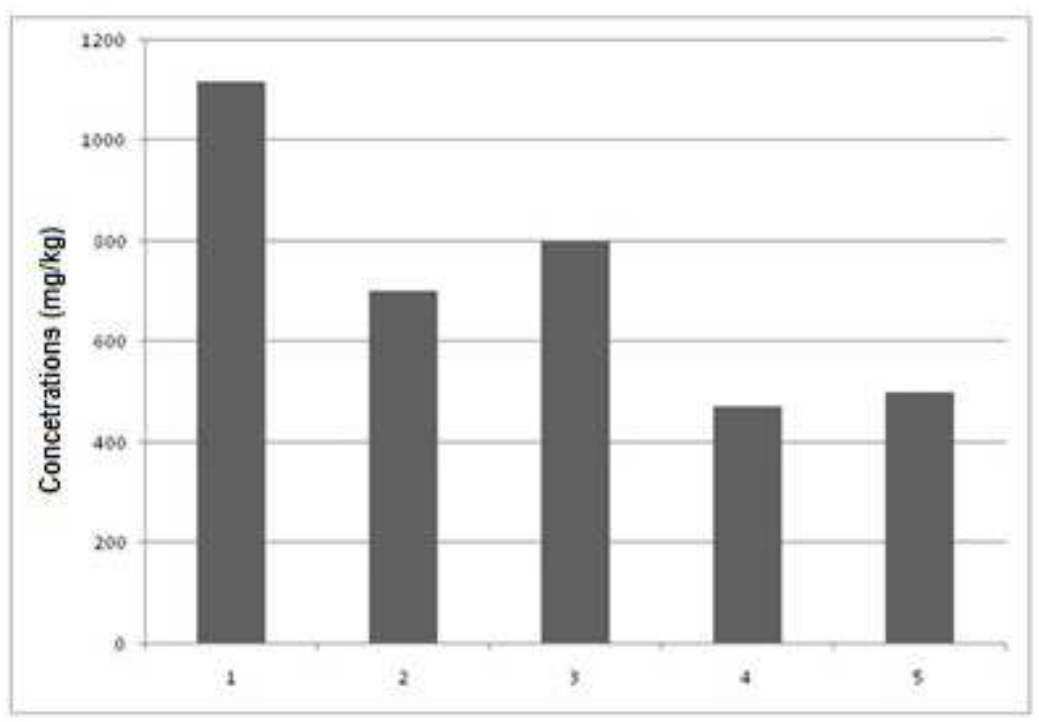

Fig. 5. Concentrations of $\mathrm{Fe}$ in the aboveground parts of the plant $P$. aviculare, in the territory of the Kraljevo (1. locality near the Ibar highway, 2. city center, 3. Ibar riverside, 4. Mataruška spa-center, 5. Drakčići village near Kraljevo).

The reasons for this may be that many factors lead to a reduction in the concentration of $\mathrm{Fe}$ and the unavailability of Fe to the plants: acidic, peaty soil, alkaline soil with plenty of lime and clay, the use of high doses of phosphorus fertilizers, excessive moisture, soil compaction, fertilization with fresh organic matter (manure), frequent use of plant protection products on the basis of $\mathrm{Cu}$ and so on and so forth. At location 4, acidic soil is present, because it is a place with a water spring that contains the highest concentration of sulfur in Southern Europe $(127 \mathrm{mg} / \mathrm{l})$. This may be the reason of the lower Fe concentration in this area. One more significant factor that influences the total quantity of $\mathrm{Fe}$ in a certain plant is that in village environments organic and inorganic substances, soil compaction and different products for plant protection are used for a variety of purposes.

\section{CONCLUSION}

The species Polygonum aviculare is efficient accumulator of heavy metals. Among the analyzed metals ( $\mathrm{Pb}, \mathrm{Ni}, \mathrm{Mn}, \mathrm{Fe}$ and $\mathrm{Cu}$ ) Polygonum aviculare well accumulate $\mathrm{Pb}, \mathrm{Cu}$ and $\mathrm{Ni}$. Based on these results and comparative analysis, relation between the concentration of metals in plants and environmental pollution was observed. Bearing in mind that the results are from a one plant species, further research must be increased, and include a larger number of plant indicators, long-term monitoring and soil sampling in order to obtain reliable data that would be useful in scientific and practical terms.

\section{Acknowledgments}

This project "Urban biodiversity - Active protection and importance" was financed by Department of Environmental Protection, City of Kraljevo during 2011. Project owner was "The Balkans" Academic Natural History Association of Kraljevo with partners: Department of Biology and Ecology, Faculty of Science, University of Kragujevac and Veterinary specialized institute "Kraljevo". 


\section{References:}

[1] Aksoy, A., Sahin, U., Duman, F. (2000): Robinia pseudoacacia L., as a possible biomonitor of heavy metal pollution in Kayseri. Turkish Journal of Botany 24: 279-284.

[2] Ali, B., Hayata, S., Fariduddina, Q., Ahmad, A. (2008): b24-epibrassinolide protects against the stress generated by salinity and nickel in Brassica juncea. Chemosphere 72: $1387-1392$.

[3] Angoletta, M., Bentivoglio, A., Giusto, D. (1993): Accumulo di metallia pesanti in piante erbacee. Inquinamento 5: 74-79.

[4] Atayese, M.O., Eigbadon, A.I., Oluwa, K.A., Adesodun, J.K. (2009): Heavy metal contamination of amaranthus grown along major highways in Lagos. African Crop Science Journal 16: 225-235.

[5] BAKer, A.J.M., BROOKS, R.R. (1989): Terrestrial higher plants which hyperaccumulate metallic elements - A review of their distribution, ecology and phytochemistry. Biorecovery 1: 81-126.

[6] Benfenati, E., Valzacchi, S., Mariani, G., Airoldi, L., Fanelli, R. (1992): PCDD, PCDF, PCB, PAH, cadmium and lead in roadside soil: relationship between road distance and concentration. Chemosphere 24: 1077-1083.

[7] Carlosena, A., Andrade, J.M., Prada, D. (1998): Searching for heavy metals grouping roadside soil as a function of motorized traffic influence. Talanta 47: 753-767.

[8] Çelik, A., Kartal, A.A., Akdoan, A., Kaska, Y. (2005): Determining the heavy metal pollution in Denizli (Turkey) by using Robinia pseudoacacia L. Environment International 31: $105-112$.

[9] Cizmecioglu, S.C., Muezzinoglu, A. (2008): Solubility of deposited airborne heavy metals. Atmospheric Research 89: 396-404.

[10] Cook, C.M., Sgardelis, S.P. (1994): Concentration Pb, $\mathrm{Zn}$ and $\mathrm{Cu}$ in Taraxacum spp. in relation to urban pollution. Bulletin of Environmental Contamination and Toxicology 53: 204-210.

[11] Davydova, S. (2005): Heavy metals as toxicants in big cities. Microchemical Journal 79: 133-136.

[12] De Varennest, A., Torres, J.F., Coutinho, M.M., Rocha, S.G., Neto, M.P. (1996): Effects of heavy metals on the growth and mineral composition od a nickel hyperacumulator. Journal of Plant Nutrition 19: 669-676.

[13] Dickinson, H.G. (2000): Pollen stigma interactions: So near yet so. Trends in Genetics 16: $373-376$.

[14] ERnst, W.H.O. (1996): Phytotoxicity of heavy metals. In: Rodriguez-BARRUeCO, C. (Ed.) Fertilizires and Enviroment. Kluwer Academic Publishers, Dordrecht, Netherlands: 423-430.

[15] Fakayode, S.O., Olu-Owolabi, B.I. (2003): Heavy metal contamination of roadside topsoil in Osogbo, Nigeria: its relationship to traffic density and proximity to highways. Environmental Geology 44: 150-157.

[16] FidORA, B. (1972): Der bleigehalt von pflanzen verkehrsnaher standorte in abhangigkeit von der vegetations periode. Berichte der Deutschen Botanichen Gesellschaft 85: 219-227. 
[17] Frey, J.W., CoRn, M. (1967): Physical and chemical characteristics of particulates in a diesel exhaust. American Industrial Hygienic Association Journal 28: 468-478.

[18] Garcia, R., Millán, E. (1998): Assessment of Cd, Pb and Zn contamination in roadside soils and grasses from Gipuzkoa (Spain). Chemosphere 37: 1615-1625.

[19] Gholami, A., Amini, H., Kar, S. (2012): Appraisal of Berry Tree (Morus alba) as a biomonitor of heavy metal contamination in Esfahan, Iran. International Journal of Agriculture and Crop Sciences 4: 578-581.

[20] HaLl, J.L. (2001): Cellular mechanisms for heavy metal detoxification and tolerance. Journal of Experimental Botany 53: 1-11.

[21] HandReEK, K.A. (1994): Effect of $\mathrm{pH}$ on the uptake of $\mathrm{Cd}, \mathrm{Cu}$ and $\mathrm{Zn}$ from soil less media containing sewage sludge. Soil and Plant 25: 1913-1927.

[22] Hanna, W.J., Grant, CL. (1962): Spectrochemical analysis of the foliage of certain trees and ornamentals for 23 elements. Bulletin of the Torrey Botanical Club 89: 293-302.

[23] Ho, Y.B., TAI, K.M. (1988): Elevated levels of lead and other metals in roadside soil and grass and their use to monitor aerial metal depositions in Hong Kong. Environmental Pollution 49: 37-51.

[24] Imperato, M., Adamo, P., Naimo, D., Arienzo, M., Stanzione, D., Violante, P. (2003): Spatial distribution of heavy metals in urban soils of Naples city (Italy). Environmental Pollution 124: 247-256.

[25] Johnson, D.L. (1980): Health effects of particulate diesel exhaust emissions. Master Thesis, University of Texas at Austin, Texas.

[26] Kastori, R., Petrović, N. (1993): Uticaj teških metala na biljke. Teški metali i pesticidi u zemljištima Vojvodine. Poljoprivredni fakultet, Institut za ratarstvo i povrtarstvo Novi Sad, 55-73.

[27] Langille, W.M., MacLean, K.S. (1976): Some essential nutrient elements in forest plants as related to species, plant part, season and location. Plant and Soil 45: 17-26.

[28] LASAT, M.M. (2000): Phytoextraction of metals from contaminated soil: a review of plant/soil/metal interaction and assessment of pertinent agronomic issues. Journal of Hazardous Substance Research 2: 1-25.

[29] LoREnZINI, G. (1999): Le piante e l'inquinamento dell'aria. Bologna, Edagricole, 1, 335.

[30] McGeoch, M.A. (1998): The selection, testing and application of terrestrial insects as bioindicators. Biological Review 73: 181-202.

[31] Memmon, A., Aktoprakligil, D., Özdemir, A., Vertis, A. (2001): Heavy metal accumulation and detoxification mechanisms in plants. Turkish Journal of Botany 25: 111121.

[32] Mengel, K., KIRKBy, E.A. (1982): Principles of Plant Nutrition, $3^{\text {rd }}$ Edition, International Potash Institute, Bern.

[33] Monni, S., Uhlig, C., Hansen, E., Magel, E. (2001): Ecophysiological responses of Empetrum nigrum to heavy metal pollution. Environmental Pollution 112: 121-129.

[34] NDIOKWERE, C.L. (1984): Astudy of heavy metal pollution from motor vehicle emissions and its effect on roadside soil, vegetation and crops in Nigeria. Environmental Pollution Series B, Chemical and Physical 7: 35-42.

[35] NRIAgU, J.O., PACYNA, J.M. (1988): Quantitative assessment of worldwide contamination of air, water and soil by trace metals. Nature 333: 134-139. 
[36] Normandin, L., Kennedy, G., Zayed, J. (1999): Potential of dandelion (Taraxacum officinale) as a bioindicator of manganese arising from the use of methylcyclopentadienyl manganese tricarbonyl in unleaded gasoline. Science of the Total Environment 239: 165171.

[37] Oliva, S.R., Castrillón, B.V., Dolores, M., Alvarez, M. (2007): Nerium oleander as a means to monitor and minimize the effects of pollution. Bocconea 21: 379-384.

[38] Pallavi, S., Rama, S.D. (2005): Lead toxicity in plants. Brazilian Journal of Plant Physiology 17: 1677-0420.

[39] PAndey, N., Sharma, C.P. (2002): Effect of heavy metals $\mathrm{Co}^{2+}, \mathrm{Ni}^{2+}$ and $\mathrm{Cd}^{2+}$ on growth and metabolism of cabbage. Plant Science 163: 753-758.

[40] Prasad, M.N.V., Freitas, H.M. (2003): Metal hyperaccumulation in plants biodiversity prospecting for phytoremediation technology. Electronic Journal of Biotechnology 6: 286290.

[41] Primault, B. (1958): En marge des futures auto rutes. Schweizer Forstwirtschaft, 109: 37-43.

[42] QAsem, M.J., Kamal, A.M. (1999): Contamination of roadside soil, plants, and air with heavy metals in Jordan. Turkish Journal of Chemistry 23: 209-220.

[43] ReZAnejad, F. (2009): Air pollution effects on structure, proteins and flavonoids in pollen grains of Thuja orientalis L. (Cupressaceae). Grana 48: 205-213.

[44] REZANEJAD, F. (2007): The effect of air pollution on microsporogenesis, pollen development and soluble pollen proteins in Spartium junceum L. (Fabaceae). Turkish Journal of Botany 31: 183-191.

[45] Soylak, M., NARin, I., Elci, L., Dogan, M. (2000): Lead concentrations of dust samples from Niðde city-Turkey. Fresenius Environmental Bulletin 9: 36-39.

[46] Stanković, D., Krstić, B., Nikolić, N. (2008): Effect of trafic on the soil contamination with polyciclyc aromatic hydrocarbons (PAHs). Journalof Biotechnology \& Biotechnological Equipment 22: 736-741.

[47] Stanković, D., KnežEvić, M., Krstić, B., Šijačić-Nikolić, M., Vilotić, D. (2011): Nickel content in plants and soil in the area of the protected natural resource „Avala” Belgrade. Bulletin of the Faculty of Forestry 103: 131-146.

[48] Stanković, D.M., Krstić, B.Đ., Šijačić-Nikolić, M.T., Knežević, M.N. (2011): Concentrations of manganese and iron in some woody and herbs plants. Nature conservation and land resources. Proceedings for Natural Sciences, Matica Srpska, Novi Sad, 121, 39-49.

[49] SuZuki, K., Yabuki, T., ONO, Y. (2008): Roadside Rhododendron pulchrum leaves as bioindicators of heavy metal pollution in traffic areas of Okayama, Japan. Environmental Monitoring and Assessment 149: 133-141.

[50] Ten Houten, J.G. (1983): Biological indicators of air pollution. Environmental Monitoring and Assessment 3: 257-261.

[51] Viard, B., Pihan, F., Promeyrat, S., Pihan, J.C. (2004): Integrated assessment of heavy metal $(\mathrm{Pb}, \mathrm{Zn}, \mathrm{Cd})$ highway pollution: bioaccumulation in soil, Gramineae and land snails. Chemosphere 55: 1349-1359. 